\title{
Characterization of Dadih: Traditional Fermented Buffalo Milk of Minangkabau
}

\author{
Marcellus Arnold (D), Yolanda Victoria Rajagukguk (D) and Anna Gramza-Michałowska *(i) \\ Department of Gastronomy Science and Functional Foods, Faculty of Food Science and Nutrition, Poznań \\ University of Life Sciences, Wojska Polskiego 31, 60-624 Poznań, Poland; marcellusarnold95@gmail.com (M.A.); \\ yola.victoria.raja@gmail.com (Y.V.R.) \\ * Correspondence: anna.gramza@up.poznan.pl; Tel.: +48-61-848-7327
}

check for updates

Citation: Arnold, M.; Rajagukguk, Y.V.; Gramza-Michałowska, A. Characterization of Dadih: Traditional Fermented Buffalo Milk of

Minangkabau. Beverages 2021, 7, 60 https://doi.org/10.3390/beverages 7030060

Academic Editors:

Panagiotis Kandylis, Lisa Solieri, Teresa Garde-Cerdan, Elena Bartkiene and Pietro Rocculi

Received: 20 July 2021

Accepted: 17 August 2021

Published: 19 August 2021

Publisher's Note: MDPI stays neutral with regard to jurisdictional claims in published maps and institutional affiliations.

Copyright: (c) 2021 by the authors. Licensee MDPI, Basel, Switzerland. This article is an open access article distributed under the terms and conditions of the Creative Commons Attribution (CC BY) license (https:// creativecommons.org/licenses/by/ $4.0 /)$.

\begin{abstract}
Dadih or dadiah is traditional fermented buffalo milk of Minangkabau, which occurs spontaneously. Dadih is commonly served as ampiang dadih, or other dishes. The microbiota found in dadih are dominated by lactic acid bacteria, and yeasts are also found. The lactic acid bacteria provide functional value, such as antimicrobial, hypocholesterolemic, antimutagenic, antioxidant, and immunomodulatory properties, as well as being the source of $\gamma$-aminobutyric acid (GABA) as an anti-stress agent and folate. Nevertheless, many challenges were observed in dadih production, including the limitation of buffalo milk production due to decreasing populations of buffalo in the last two decades, unstandardized dadih production due to the spontaneous fermentation in natural bamboo tubes, and safety problems as no heat treatment is applied in the production of dadih. These problems impede the development of dadih production, thus is it important to improve buffalo cultivation through artificial insemination programs, using different types of milk and pasteurization processes in dadih production, and incubator development to accelerate the fermentation period.
\end{abstract}

Keywords: dadih; buffalo milk; lactic acid bacteria; fermentation; health value; traditional food

\section{Introduction}

Indonesia is a multicultural country with more than 1300 ethnic groups [1]. Each region or ethnic group in Indonesia has unique traditional foods with a different history, purpose, raw materials, and taste. Traditional food can be the symbol or historical evidence that differentiates one ethnic group from another. Minangkabau is one of the well-known ethnic groups in Indonesia. In 2010, the total population of the Minangkabau (Minang) people was $2.73 \%$ of the total population in Indonesia, and dominantly resided in West Sumatra province (Figure 1) [1]. Besides lamang [2], lamang tapai [3], rendang [4], and ketupat bareh [5], dadih is also known as the authentic traditional food originated from this region.

Dadih (Figure 2) is a fermented buffalo milk product in a bamboo tube, which has been prepared and consumed by the Minang people for hundreds of years. It is a yogurt-like product with a smooth and glossy surface, even consistency, creamy color, good aroma, and sour taste. Minang people call it as dadiah, and it is easily found in Padang Panjang, Bukittinggi, Lima Puluh Kota, Solok, and Tanah Datar regions [6]. Since dadih is produced in home industries, it is not very popular compared to other fermented milk products [7].

Various dishes can be made from dadih (Figure 3). One of the popular dishes in Minangkabau made from dadih is ampiang dadih (Figure 3A). Additionally, dadih is also served as a traditional dish at weddings and ethnic ceremonies while giving the title "Datuk" (the title of respect) in West Sumatra [6]. 


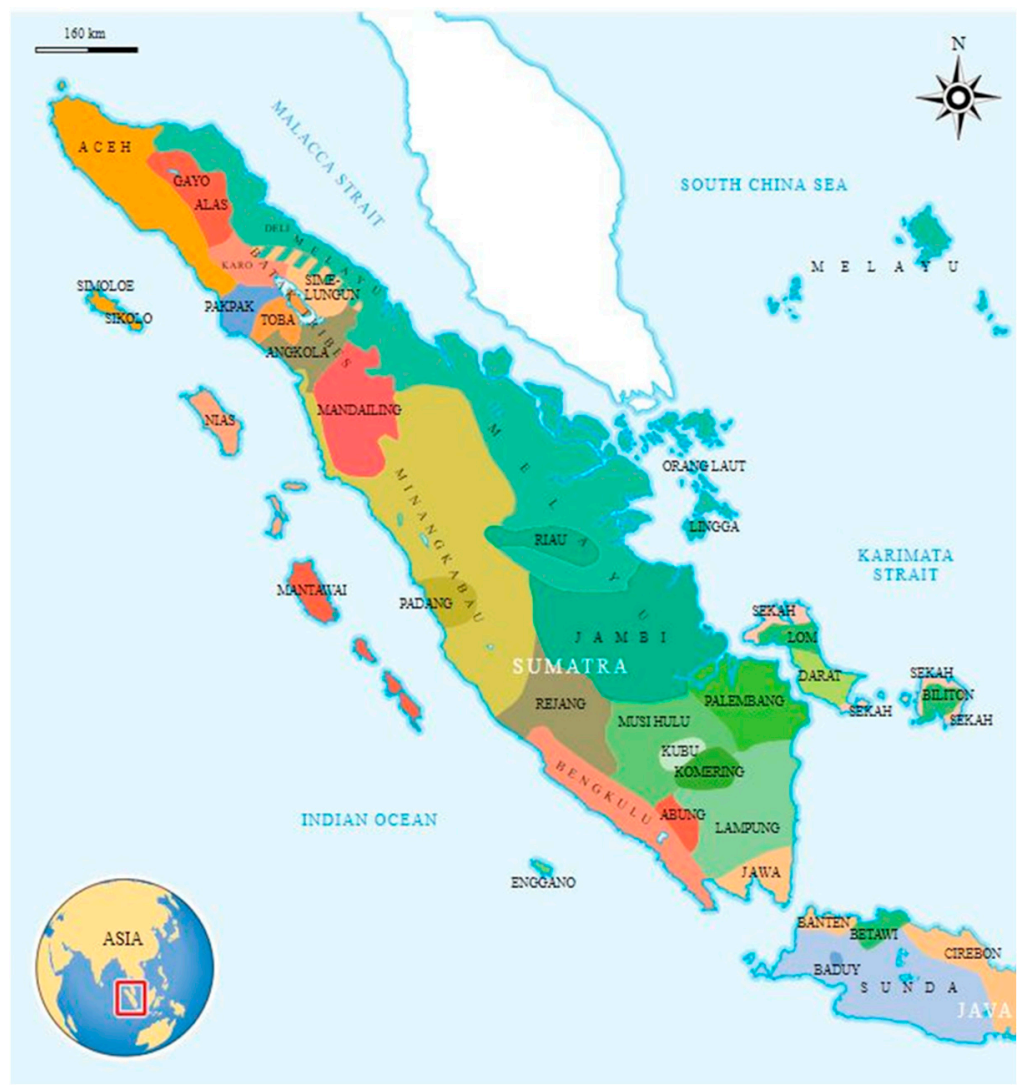

Figure 1. The map of ethnic groups in Sumatra islands and surroundings, Indonesia. The light and dark olive color on the center of the map shows the Minangkabau ethnic group, producing the authentic traditional fermented buffalo milk-dadih. Picture by: Gunawan Kartapranata, based on "Peta Suku Bangsa di Indonesia" at National Museum of Indonesia, Jakarta (CC BY-SA 3.0, source: https://upload.wikimedia.org/wikipedia/commons/archive/8/8c/20180810080403 \%21Sumatra_Ethnic_Groups_Map_en.svg) (accessed on 16 May 2021).
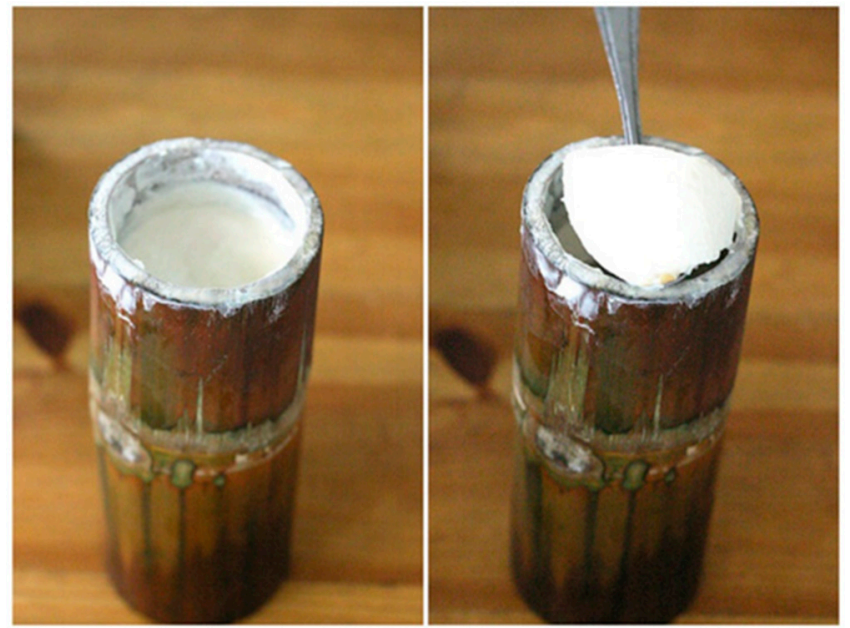

Figure 2. Dadih. The bamboo tube is used as the container during buffalo milk fermentation process. The resulting fermented buffalo milk—dadih has a smooth and glossy surface, even consistency, creamy-white color, pleasant aroma, and sour taste. Photo by: I. Soemardjan (CC BY-NC-ND 2.0, source: https:/ / www.flickr.com/photos/94093643@N00/180430205 (accessed on 16 May 2021) and https:/ / www.flickr.com/photos/indrani/180430424/in/photostream/) (accessed on 16 May 2021). 

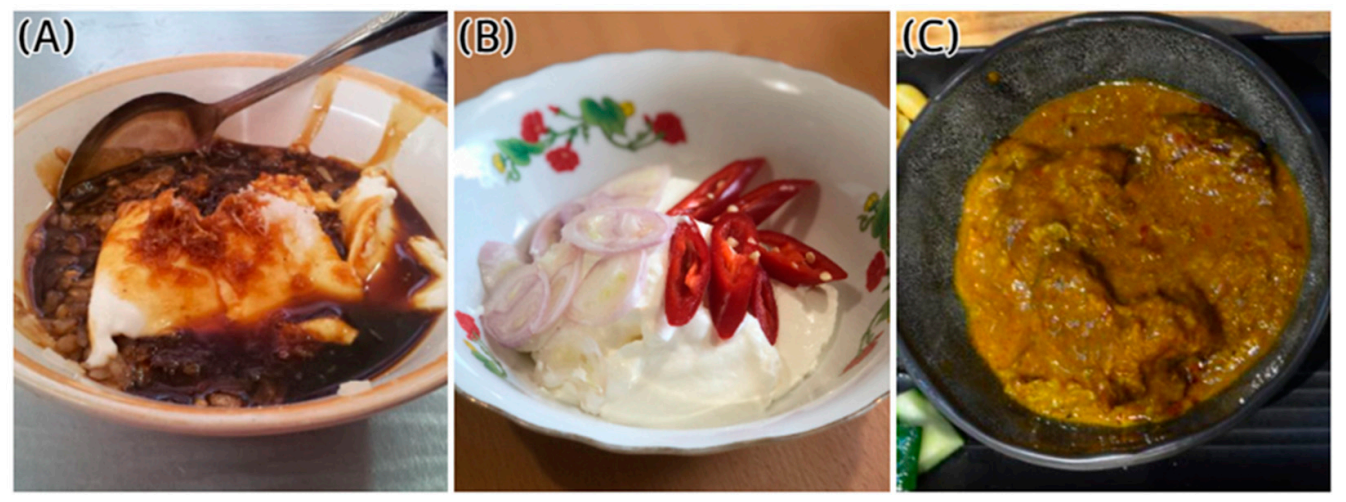

Figure 3. Dadih-fermented buffalo milk in various dishes. (A) Ampiang dadih (ampiang dadiah). Traditional food of Minangkabau, consists of dadih, ampiang (glutinous rice flakes), shaved ice, shredded coconut or coconut milk, and palm sugar syrup as the topping. Photo by: Dinda (CC BYNC 2.0, source: https:/ / www.flickr.com/photos/41912023@N07/8908205779). (B) Dadih—fermented buffalo milk served with sliced shallot and chili. Authors hold the copyright. (C) Beef curry (rendang). Dadih—fermented buffalo milk can be used as the substitute of coconut milk in beef curry. Photo by: Alpha (CC BY-NC 2.0, source: https: / / www.flickr.com/photos/avlxyz/39545761832/in/ photostream/) (accessed on 29 May 2021).

The fermentation in dadih production occurs spontaneously, without inoculating of any starter cultures and without heat or pasteurization [8]. As no heat treatment is applied in dadih production, dadih does not fulfill any standards which require pasteurization of the raw milk [6]. The coagulation of fresh buffalo milk into dadih occurs due to the presence of indigenous enzymes and indigenous natural lactic acid bacteria (LAB) in buffalo milk [6]. The indigenous $\mathrm{LAB}$ may vary from one place to another and from time to time due to this spontaneous fermentation [6,7]. Despite good hygiene practice not being implemented in the production process of dadih, the natural LAB found in dadih contributes to the safety of this product [6]. However, the standardization of the production process is needed to ensure safety and to maintain the properties of dadih.

Dadih is known as a potential probiotic as it has a huge amount of LAB (typically $10^{8}$ colony-forming units (cfu/g) [8,9], which potentially support the intestinal wall and has many benefits for life and health of the host [10]. These LAB of dadih were reported to have antimicrobial (antipathogenic) properties [10], hypocholesterolemic properties [11-13], antimutagenicity properties [14], antioxidant properties [15], immunomodulatory properties [16,17], anti-stress properties [18,19], and folate-producing ability [20].

Nevertheless, many challenges were observed in dadih production which triggers the local government and many researchers to contribute in finding the best solution. Therefore, this article aims to generate and spread the knowledge about the story behind dadih in Minangkabau, processing of traditional dadih, maturation of dadih, microbiota found in dadih, nutritional value and chemical analysis of dadih, functional value, dadih in daily diet, challenges, and future trends of dadih.

\section{Buffalo, Minangkabau, and Dadih}

For centuries, the water buffalo (Bubalus bubalis, the domestic buffalo) was an important animal to the Minang people. The buffaloes were used by local people for transportation, delivering goods, plowing fields, milling sugar cane in sugar production, and for tourism purposes, such as buffalo fighting or adu kerbau [7]. Furthermore, the roof of the traditional Minangkabau house, also known as Rumah Gadang, resembles the horns of the buffalo and this also symbolizes the victory of the buffalo of Minangkabau against the Javanese buffalo in the territorial dispute [21].

The products from buffalo itself were also consumed, for example, as a source of meat, milk (including dadih production), skin crackers, while the excrement of buffalo is used for 
organic fertilizer and biogas production. The production of dadih from buffalo milk can help the economy and support the food security of the Minang people [7]. Besides that, for the Minang people, dadih also symbolizes the expression of the family host's feelings towards their guests [22].

\section{Processing of Traditional Dadih}

The main materials used in dadih production are buffalo milk, bamboo tubes, and banana leaves. The buffalo milk generally contains higher total solids content compared to other mammals' milk (Table 1), especially due to the higher casein and fat content, which are responsible for the creamy, thick body, and custard-like consistency of dadih [6]. The higher fat content of the milk results in softer texture and developed flavor of dadih $[6,11]$.

Table 1. Comparison of mammals' milk composition.

\begin{tabular}{cccccccc}
\hline \multirow{2}{*}{ Mammals } & \multicolumn{7}{c}{ Percent Composition $(\% \boldsymbol{w} / \boldsymbol{v})$ of Mammals' Milk } \\
\cline { 2 - 7 } & Fat & Casein & Whey Protein & Lactose & Ash & Total Solid & Reference \\
\hline Buffalo & 7.4 & 3.2 & 0.6 & 4.8 & 0.8 & 17.2 & {$[6,23]$} \\
Cow & 3.7 & 2.8 & 0.6 & 4.8 & 0.7 & 12.7 & {$[6,23]$} \\
Goat & 4.5 & 2.5 & 0.4 & 4.1 & 0.8 & 13.2 & {$[6,23]$} \\
Sheep & 7.4 & 4.6 & 0.9 & 4.8 & 1.0 & 19.3 & {$[6,23]$} \\
Mare & 1.9 & 1.3 & 1.2 & 6.2 & 0.5 & 11.2 & {$[6,23]$} \\
Camel & 5.4 & 2.9 & 1.0 & 5.1 & 0.7 & 15.0 & {$[24]$} \\
Sow & 6.8 & 2.8 & 2.0 & 5.5 & ND & 18.8 & {$[6,23]$} \\
\hline
\end{tabular}

ND: Not determined; $w / v$-weight/volume.

Bamboo tubes are chosen as the containers during fermentation because they have hygroscopic properties to keep the product from whey separation, and the bitter taste of bamboo can prevent contamination against ants [6,7]. Many types of bamboo used in dadih fermentation were reported, including bamboo ater (Gigantochloa atter), bamboo gombong (Gigantochloa verticillata), bamboo lengka tali (Gigantochloa hasskarliana), bamboo ampel (Bambusa vulgaris), and bamboo betung (Dendrocalamus asper) $[6,7,25]$. Among these bamboo types, the native Minang people prefer to use bamboo gombong [6]. The number of indigenous microbes found on the inner surface of bamboo was $2.5 \times 10^{2}-1.0 \times 10^{3}$ $\mathrm{cfu} / \mathrm{cm}^{2}$, and acid-producing proteolytic bacteria were found to be in the majority [26], followed by yeast [25]. The type of bamboo also affects the flavor of the resulting dadih [7]. By analyzing the flavor, color, aroma, and texture in hedonic evaluation, the salad dressing from goat milk dadih fermented in bamboo ampel was significantly preferred $(p<0.05)$ compared to that in bamboo gombong, especially within 2 days of the fermentation process [25].

Banana leaves are commonly used to cover the bamboo tube during dadih fermentation. The purpose of using banana leaves is to create the facultative anaerobic condition which is optimum for the fermentation process, as well as to avoid unwanted contamination [27]. However, depending on the region, not only banana leaves, but also taro leaves or plastics are used to cover the bamboo [28]. To tie the cover, banana bark or rubber bands are used [27].

The traditional production process of dadih is shown in Figure 4. In West Sumatra, most buffaloes produce around $2 \mathrm{~L}$ of milk a day [7]. After milking the buffalo, the raw buffalo milk (free from antibiotics) is directly filtered to reduce the physical contamination such as stones and grass. The filtered milk is then poured into the bamboo tube, covered with banana leaves, and tied with a rubber band or banana bark. The fermentation process occurs spontaneously at room temperature $\left(28-30^{\circ} \mathrm{C}\right)$ for $24 \mathrm{~h}$ [6] or even 2-3 days [11,13]. The indigenous LAB and proteases will perform the lactic acid fermentation as well as proteolytic activity to produce the dadih with a thick consistency, solid texture, smooth surface, and pleasant flavor. The fermentation by LAB is very important to reduce the contaminant by pathogens and spoiling bacteria, thus makes dadih safer to consume. The possible mechanisms are (1) by producing the inhibitory metabolites, for example, the organic acids (mainly lactic acid) during the fermentation process, which then decreases 
the $\mathrm{pH}$ of the medium and pathogens cannot grow well [6]; (2) by producing bacteriocins (see Section 7.1).

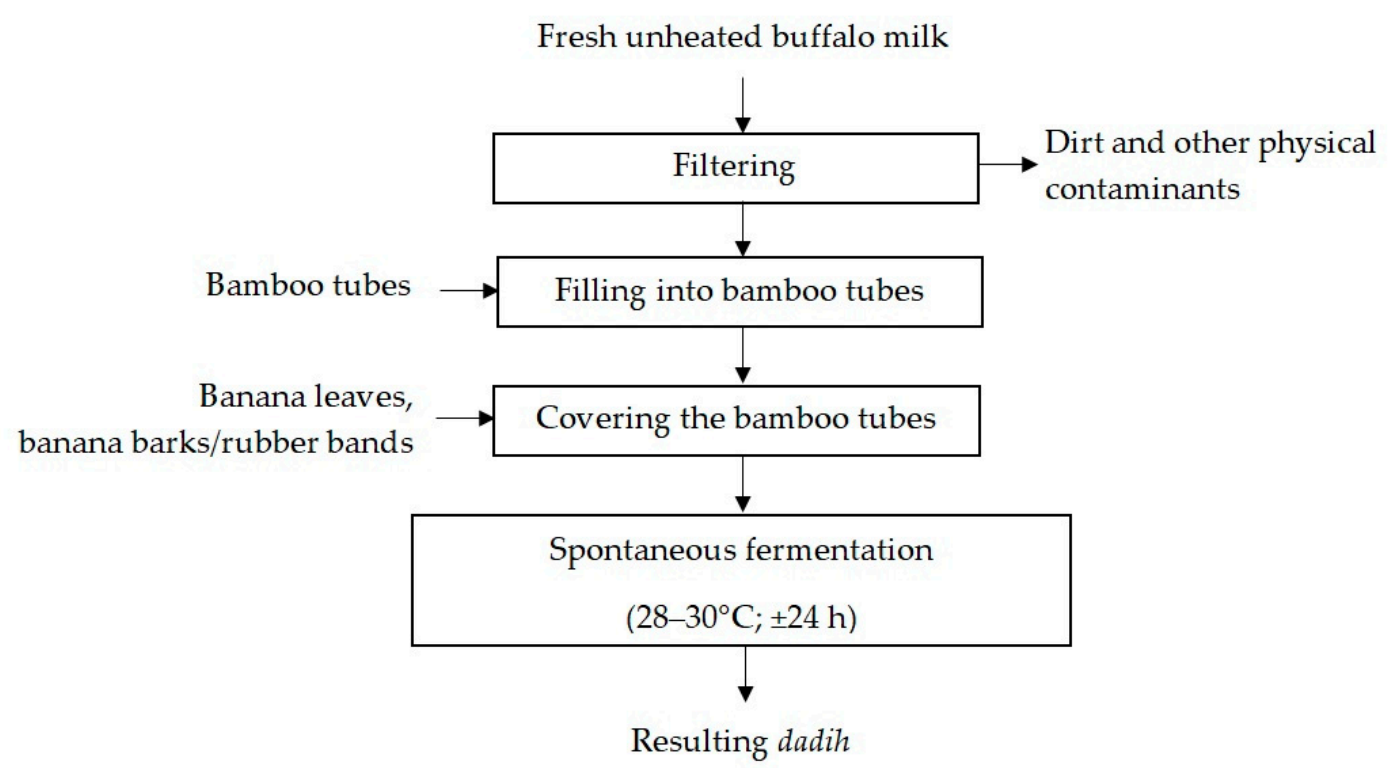

Figure 4. Traditional production process of dadih—fermented buffalo milk. Authors hold the copyright.

Dadih is similar to dahi from India [8,29], however, they have some differences. In dadih production, heat treatment is not applied to the raw buffalo milk, and no starter culture is added for fermentation. While in dahi production, the pasteurization process of raw buffalo or cow milk or a combination of both kinds of milk is applied before fermentation, and the back-slopping method (a small quantity of dahi from the previous lot is used as a starter culture of the next lot) is used $[29,30]$. In comparison to yogurt, the fermentation time of dadih is longer ( $24 \mathrm{~h}$ up to $3 \mathrm{~d}$ ) than yogurt $(4 \mathrm{~h})$. Furthermore, the mesophilic LAB is involved at $28-30{ }^{\circ} \mathrm{C}$ in dadih fermentation, while thermophilic LAB is involved at $45^{\circ} \mathrm{C}$ in yogurt fermentation [6,29]. The involvement of indigenous yeasts in dadih fermentation also differs the dadih from yogurt [31].

\section{Maturation of Dadih}

Carbohydrate fermentation, proteolytic activity, and lipid metabolism contribute to the formation of the desired structure and flavor of dadih. In carbohydrate catabolism, LAB converts lactose into lactic acid by involving $\beta$-galactosidase and lactic acid fermentation. The resulting lactic acid decreases the $\mathrm{pH}$ value of buffalo milk and contributes to protein precipitation or coagulation of buffalo milk, so the curd or dadih is formed. Decreasing $\mathrm{pH}$ value from 6.92 (raw buffalo milk) to 4.65 after 2 days of dadih fermentation was observed [32]. Through carbohydrate catabolism, small quantities of flavor compounds are also formed through the volatile fatty acids, ethanol, acetoin, acetic acid, butanone, diacetyl, and acetaldehyde [29]. Lactic acid, as the major fermentation product, is produced by the homofermentative LAB, such as Lactobacilli, Lactococci, Pediococci, and Streptococci, while flavor formation is formed by heterofermentative $\mathrm{LAB}$ such as Levilactobacillus brevis, Limosilactobacillus fermentum, and Leuconostoc sp. [29]. Lactic acid formed by LAB contributes to the destabilization of casein micelles to form curd and gives the distinctive and characteristic sharp acidic taste of dadih [29]. Moreover, dadih is safely consumed by people with lactose intolerance [33], as during dadih fermentation, the $\beta$-galactosidase activity and lactic acid fermentation can help the digestion of lactose.

The proteolytic system of LAB is complicated, especially in turning milk casein into free amino acids and peptides which are needed for LAB growth. However, the overall proteolytic system of LAB is very weak. To support LAB growth, raw buffalo milk possesses 
indigenous enzymes that may also contribute to making amino acids and peptides. Since heat is not applied during dadih production, the thermal breakdown of raw buffalo milk protein, denaturation, and coagulation of albumins and globulins will not occur. So, the degradation of protein will be catalyzed by bacterial or native proteases. The proteolytic activity from milk proteases, such as plasmin or proteases of bacterial origin, help in the thickening, gelation, and coagulation process of buffalo milk in dadih production [6].

The natural lipases in the raw buffalo milk may take part in lipid metabolism, while the insignificant amount of free fatty acids and volatile fatty acids are released by microbial contaminants of the buffalo milk [6]. The high-fat content of buffalo milk (twice as high as cow milk) (Table 1) contributes to the creamy textures and various flavors in dadih [6].

\section{Microbiota of Dadih}

In spontaneously fermented products, various types of microbiotas might be involved, including, but not limited to, LAB and yeasts. In dadih, the indigenous LAB of buffalo milk are the main group of microbes that are involved in dadih fermentation. The LAB will dominate and grow during the fermentation, decrease the pathogenic and spoilage bacteria, and develop the flavor of dadih. The total viable LAB count was in the range of $1.42 \times$ $10^{8}-3.80 \times 10^{8} \mathrm{cfu} / \mathrm{g}$ [34]. Various types of LAB can be found from one place to another in West Sumatra [35]. Leuconostoc paramesenteroides, which produce acetic acid, diacetyl, and other volatiles as the aromatic compounds were reported as the predominant strains of LAB [36]. Nuraida [37] reported that Leuconostoc mesenteroides, Lactococcus lactis subsp. lactis, Levilactobacillus brevis, Lacticaseibacillus casei, Lactiplantibacillus plantarum subsp. plantarum, Enterococcus faecium, Limosilactobacillus fermentum, and Lacticaseibacillus rhamnosus were found in dadih from buffalo milk. The unhygienic process applied in dadih production becomes the possible reason, as Enterococci group bacteria, such as Enterococcus faecalis was also found in dadih $[29,38]$. Furthermore, the types of fermentation (spontaneous and back-slopping) affect the diversity of LAB in dadih, as black-slopping fermentation results in greater diversity compared to spontaneous dadih fermentation [39]. Bifidobacterium (18\% of total microbiota composition) was found in non-pasteurized dadih from the Palupuh region, prepared using back-slopping method [40]. The various types of LAB in dadih are mentioned in detail in Table 2.

Not only LAB, but other types of microbes were also found in dadih. A higher abundance of species of the order Serratia and Burkholderiales, and a lower abundance of Brachybacterium were found in dadih with the back-slopping method [40]. Three yeast species, namely Saccharomyces cerevisiae, Candida metapsilosis, and Kluyveromyces marxianus were found in dadih with C. metapsilosis as the most predominant species [32]. The different types of yeast in dadih, such as Candida stelimalicola and Pichia jadinii, were also reported [41]. After 2 days of fermentation, the total viable yeast count was $6.85 \mathrm{log} \mathrm{cfu} / \mathrm{g}$, or about $7.08 \times 10^{6} \mathrm{cfu} / \mathrm{g}$ in dadih from the Solok region [30].

Candida sp., including C. metapsilosis, are normally found in the gastrointestinal tract, but they are also known as opportunistic pathogens which may be considered as the cause of disseminated candidiasis [42]. C. metapsilosis was isolated in the inner part of bamboo tubes of dadih [32]. A study reported that $C$. metapsilosis was found not only dadih, but also in Chicha, a spontaneously fermented beverage, made from maize [43]. Yeasts and LAB grow simultaneously in the production of organic acids by LAB, which lower the $\mathrm{pH}$ of the medium, and may favor the growth of yeasts. While, yeasts provide the growth factors for the LAB, such as vitamins and components of soluble nitrogen [43]. That might be the reason why C. metapsilosis could survive and be found in dadih. 
Table 2. Types of lactic acid bacteria found in dadih—fermented buffalo milk.

\begin{tabular}{|c|c|c|}
\hline Region in West Sumatra & Types of Lactic Acid Bacteria & References \\
\hline Bukittinggi and Padang Panjang & Lactobacillus sp., Lactococcus sp., and Leuconostoc sp. & [34] \\
\hline Bukittinggi & $\begin{array}{c}\text { Lactococcus lactis subsp. lactis, Levilactobacillus brevis, Lactiplantibacillus } \\
\text { plantarum subsp. plantarum, Lacticaseibacillus casei, Lacticaseibacillus } \\
\text { paracasei, Leuconostoc mesenteroides }\end{array}$ & [13] \\
\hline $\begin{array}{l}\text { Lima Puluh Kota, Agam, Tanah Datar, } \\
\text { Solok }\end{array}$ & $\begin{array}{c}\text { Levilactobacillus brevis, Weissella viridescens, Lentilactobacillus buchneri, } \\
\text { Lactiplantibacillus plantarum subsp. plantarum, Leuconostoc } \\
\text { mesenteroides, Leuconostoc paramesenteroides, Streptococcus lactis subsp. } \\
\text { diacetylactis, Streptococcus faecium, Streptococcus raffinolactis, Lactococcus } \\
\text { piscium }\end{array}$ & {$[44]$} \\
\hline Payakumbuh & Lactiplantibacillus plantarum subsp. plantarum & [45] \\
\hline Sijunjung & Lactiplantibacillus plantarum subsp. plantarum & [46] \\
\hline Solok & Lactiplantibacillus plantarum subsp. plantarum & [47] \\
\hline Payakumbuh & Lactobacillus sp. & [48] \\
\hline Palupuh & Lactobacillus sp., Lactococcus sp., Leuconostoc sp. & [40] \\
\hline Gadut & $\begin{array}{c}\text { Lactiplantibacillus plantarum subsp. plantarum, Lactococcus lactis subsp. } \\
\text { cremoris, Lactococcus lactis subsp. lactis }\end{array}$ & [39] \\
\hline Kamang & $\begin{array}{c}\text { Lactiplantibacillus pentosus, Lactococcus lactis subsp. lactis, Pediococcus } \\
\text { pentosaceus, Lactococcus lactis subsp. cremoris, Lactiplantibacillus } \\
\text { plantarum subsp. plantarum }\end{array}$ & [39] \\
\hline
\end{tabular}

\section{Nutritional Value and Chemical Analysis of Dadih}

The nutritional value and chemical analysis of dadih from different regions, as well as the developed dadih using different types of milk (see Section 9 for the backgrounds of developed dadih), was reported by previous studies, described in Tables 3 and 4, respectively. In Table 3, the nutritional value and chemical analysis of dadih were different from one region to another. For example, the $\mathrm{pH}$ and total acidity of dadih varied between regions. Helmizar et al. [9] reported that the type of buffalo feed may impact the $\mathrm{pH}$ and acidity of dadih. As an example, the grass (Imperata cylindrica) in Agam, and banto grass (Leersia hexandra Sw.) with rice straws in Tanah Datar were used to feed the buffaloes. These weeds contain several compounds such as malic and citric acid with different contents, which may affect the $\mathrm{pH}$ and acidity of the resulting dadih. Furthermore, the different types of bamboo (each type has different thickness, porosity, and other characteristics) used to produce dadih and the addition of food supplements given to the buffaloes in different regions may also affect the chemical composition of dadih, such as protein, fat, water content, etc. [9]. The uncontrolled production that causes different chemical compositions of dadih in different regions leads to the idea of production standardization, which is described in Section 9.

Table 3. Nutritional value of dadih—fermented buffalo milk from different regions in West Sumatra.

\begin{tabular}{cccccc}
\hline \multirow{2}{*}{$\begin{array}{c}\text { Chemical Characteristics of } \\
\text { Dadih }\end{array}$} & \multicolumn{5}{c}{ Regions of West Sumatra } \\
\cline { 2 - 6 } & \multicolumn{2}{c}{ Agam } & Sijunjung & Solok & Tanah Datar \\
\hline Protein (\%) & 10.89 & 7.06 & 5.01 & 6.91 & 12.41 \\
\hline Fat (\%) & 18.00 & 8.17 & 6.50 & 7.98 & 5.70 \\
\hline Carbohydrate (\%) & 8.03 & ND & ND & ND & 14.92 \\
\hline Water content (\%) & 61.94 & 82.40 & 75.45 & 81.79 & 66.09 \\
\hline Ash content (\%) & 1.14 & 0.91 & 0.68 & 0.92 & 0.72 \\
\hline $\mathrm{pH}$ & 4.33 & 4.80 & 4.74 & 4.76 & 4.55 \\
\hline
\end{tabular}


Table 3. Cont.

\begin{tabular}{ccccccc}
\hline \multirow{2}{*}{$\begin{array}{c}\text { Chemical Characteristics of } \\
\text { Dadih }\end{array}$} & \multicolumn{5}{c}{ Regions of West Sumatra } \\
\cline { 2 - 6 } & \multicolumn{2}{c}{ Agam } & Sijunjung & Solok & Tanah Datar \\
\hline Acidity (\%) & 1.70 & 1.28 & 1.17 & 1.32 & 0.51 \\
\hline Reference & {$[9]$} & {$[49]$} & {$[49]$} & {$[49]$} & {$[9]$} \\
\hline
\end{tabular}

ND: Not determined.

Some studies reported the substitution of buffalo milk using other types of milk as the substrate of dadih. In this case, starter culture may be needed to start the fermentation process and to standardize the production process (see Section 9). The fat content of dadih from buffalo milk and cow milk ranged from 5.70 to $18.00 \%$ (Table 3), and 7.03 to $10.96 \%$ (Table 4), respectively. Although the fat and total protein content of cow milk are lower than those of buffalo milk (Table 1), some additional processes, such as evaporation and addition of skim milk could increase the total solid content of cow milk, including fat and protein, to achieve the desirable dadih properties [50]. The fat content of dadih from soy milk is still lower than that from other kinds of milk, despite that skim milk was added to increase the total solid content.

Table 4. Nutritional value of developed dadih—fermented milk made from different types of milk.

\begin{tabular}{|c|c|c|c|c|c|}
\hline \multirow{2}{*}{$\begin{array}{c}\text { Chemical } \\
\text { Characteristics of } \\
\text { Dadih }\end{array}$} & \multicolumn{5}{|c|}{ Dadih from Other Types of Milk } \\
\hline & \multicolumn{3}{|c|}{ Cow Milk } & \multirow{2}{*}{$\begin{array}{c}\text { Goat Milk } \\
\text { Spontaneous }\end{array}$} & \multirow{2}{*}{$\begin{array}{c}\text { Soy Milk } \\
\text { Back-slopping method } \\
\text { using dadih from } \\
\text { Bukittinggi }(4 \% w / w)\end{array}$} \\
\hline $\begin{array}{l}\text { Starter culture } \\
\text { (concentration) }\end{array}$ & $\begin{array}{c}\text { L. plantarum }+ \text { L. } \\
\text { acidophilus }+ \text { B. bifidum } \\
(3 \% w / v)\end{array}$ & $\begin{array}{c}L . \text { plantarum }+L . \\
\text { acidophilus }(3 \% w / v)\end{array}$ & $\begin{array}{l}\text { Back-slopping method } \\
\text { using dadih from } \\
\text { Bukittinggi }(4 \% w / w)\end{array}$ & & \\
\hline Protein $(\%)$ & 3.53 & 4.27 & 9.79 & 3.75 & 4.65 \\
\hline Fat $(\%)$ & 10.96 & 7.59 & 7.03 & ND & 2.91 \\
\hline Carbohydrate (\%) & ND & ND & ND & ND & ND \\
\hline Water content $(\%)$ & 83.15 & 73.72 & ND & ND & ND \\
\hline Ash content $(\%)$ & 0.90 & 0.52 & ND & ND & ND \\
\hline $\mathrm{pH}$ & 3.49 & 4.29 & ND & 6.54 & ND \\
\hline Acidity (\%) & 3.45 & 0.64 & ND & 0.31 & ND \\
\hline Reference & [51] & [52] & [53] & [54] & [53] \\
\hline
\end{tabular}

ND: Not determined; $w / v$ : weight/volume; $w / w$ —weight/weight.

\section{The Functional Value of Dadih}

With a high amount of viable $\mathrm{LAB}$, dadih becomes a potential probiotic and provides many potential beneficial effects on health [10], including antimicrobial, immunomodulatory, antimutagenic, antioxidant, and hypocholesterolemic properties, and as a source of $\gamma$-aminobutyric acid (GABA) and folates.

\subsection{Antimicrobial Properties}

The decrease $\mathrm{pH}$ levels, competition for substrates, and the production of substances with a bactericidal or bacteriostatic action are several factors that result in the LAB from dadih possessing antimicrobial activity [46]. Lactobacillus spp., which is the most superior probiotic found in dadih, showed antimicrobial activity against Escherichia coli, Staphylococcus aureus, and Salmonella enteritidis with inhibitory diameter $11.54 \mathrm{~mm}, 10.27 \mathrm{~mm}$, and $16.31 \mathrm{~mm}$, respectively [55]. L. plantarum strain 8m-21 isolates of dadih from the Air Dingin region (Solok) exhibited antimicrobial activity against $E$. coli O157. The inhibitory zone of $L$. plantarum strain $8 \mathrm{~m}-21$ against $E$. coli $\mathrm{O} 157$ was $20.25 \mathrm{~mm}$, greater than penicillin $(2.70 \mathrm{~mm})$, ampicillin $(15.20 \mathrm{~mm})$, and kanamycin $(14.19 \mathrm{~mm})$ as the controls after $24 \mathrm{~h}$ of incubation at $37^{\circ} \mathrm{C}$ [10]. Furthermore, L. plantarum isolated from dadih from the Sijunjung region showed $12 \mathrm{~mm}, 13.5 \mathrm{~mm}$, and $12 \mathrm{~mm}$ of inhibitory zone against E. coli, S. aureus, and S. typhi, respectively, after $36 \mathrm{~h}$ of incubation [46]. Different antimicrobial activities of L. plantarum in dadih originated from the Solok, Sijunjung, and Payakumbuh regions against S. aureus, E. 
coli, and S. typhi were investigated, with L. plantarum in dadih from Payakumbuh showed the highest antimicrobial effect [56]. In dadih made from soy milk, L. plantarum strain BDL11 exhibited the highest bacteriocin activity against Listeria monocytogenes (inhibitory zone diameter $8 \pm 0.02 \mathrm{~mm}$ ) compared to other strains [57].

After $7 \mathrm{~h}$ of contact with L. plantarum from dadih from the Payakumbuh region, the death percentage of $33.3 \%$ of $S$. aureus colony, $27.27 \%$ of E. faecalis colony, and $23.07 \%$ of E. coli colony were reported, demonstrating that L. plantarum more effectively inhibits Gram-positive bacteria (S. aureus and E. faecalis) than Gram-negative bacteria (E. coli) [45]. This might be due to the outer membrane of Gram-negative bacteria, which functions as an efficient permeability barrier and is able to exclude macromolecules (i.e., bacteriocins or enzymes) and hydrophobic substances (i.e., hydrophobic antibiotics) [58]. Bacteriocin produced by L. plantarum is plantaricin that shows antimicrobial activity [59], including against Staphylococcus spp. [60]. The L. plantarum isolated from this dadih also survived in the concentration of $0.5 \%$ bile salts, and is resistant to acidic media until $\mathrm{pH} 2$, which makes it a good probiotic that can inhibit the growth of pathogenic bacteria in the digestive tract [45].

Due to the beneficial antimicrobial properties from bacteriocin of LAB from dadih, it can be used as a natural preservative to prevent food-borne disease [61], including as a natural preservative of chicken meat [62].

\subsection{Hypocholesterolemic Properties}

The hypocholesterolemic activity of dadih was reported by previous studies. LAB in dadih may alter serum cholesterol by either directly binding to dietary cholesterol, deconjugation of bile salts, or in combination [63]. The bile salt hydrolase activity may contribute to the reduction of cholesterol, as the free bile salts (deconjugated) are less re-absorbable in the intestine compared to the conjugated bile salts, and may be excreted in the feces [13].

It was reported that L. fermentum I-11 and Leuconostoc lactis subsp. lactic I-2775 could be recommended as a probiotic to prevent coronary heart disease as those were tolerant to acid and ox gall (bile) and deconjugated sodium taurocholate and bound cholesterol [63]. Furthermore, taurocholate-deconjugating abilities were observed in Lactococcus lactis subsp. lactis IS-10285 and IS-29862 [13]. In rat studies, the rats fed with fermented kinds of milk made from Lactococcus lactis subsp. lactis IS-10285 from dadih exhibited significantly $(p<0.05)$ lower total bile acids in serum [12].

\subsection{Antimutagenic Properties}

The mechanism of the antimutagenic effect of LAB in dadih takes place because of the bonds between mutagens or carcinogens with the peptidoglycan contained in the LAB. Mutagens and carcinogens which are bound will be excreted via feces and urine [10].

The LAB isolated from dadih, such as Leuconostoc paramesenteroides R-62, R-8, Streptococcus lactis subsp. diacetylactis R-63, and Streptococcus cremoris R-48 were reported to have high antimutagenic activities toward various mutagens, such as $\mathrm{N}$-nitroso-dimethylamine (NDMA), N-nitroso-diethylamine (NDEA), N-nitroso-piperidine (NPIP), and N-nitrosopyrrolidine (NPYR), which has led to the suggestion that some of these compounds may contribute to carcinogenesis in humans. Furthermore, the antimutagenic properties of milk cultured with LAB from dadih, especially L. casei subsp. casei R-52, against mutagenic terasi (traditional Indonesian shrimp paste), was observed [64]. Milk cultured with Lactococcus lactis subsp. cremoris R-48, Leuconostoc mesentroides R-51, and Lactococcus lactis subsp. casei R-68 isolated from dadih exhibited high inhibition against the mutagenicity of both heated salty and sweet tauco (traditional Indonesian saline paste made from fermented yellow soybeans) [65]. However, only L. mesentroides R-51 was tolerant to both acid and bile, and can be used as a probiotic in preventing the mutagenesis caused by mutagenic heated food like tauco [65]. In vivo antimutagenic properties of E. faecium IS-27526 isolated from dadih from Bukittinggi toward Trp-P1 were also observed [14]. 


\subsection{Antioxidant Properties}

Free peptides and amino acids that are released after milk protein breakdown possess antioxidant properties [66]. The antioxidant activity of cow milk dadih fermentation using $1 \%$ starter culture of L. casei and L. plantarum (ratio 1:1) using 2,2-diphenyl-1-picrylhydrazyl-hydrate (DPPH) method was observed [15]. It was stated that $72 \mathrm{~h}$ of fermentation in the making of cow milk dadih is the most optimum length of fermentation to receive the highest antioxidant activity [15]. The soluble protein of buffalo milk dadih (3 days of fermentation) originating from the Agam region showed higher antioxidant activities in Fe reducing power, scavenging activity against 2,2'-azino-bis(3-ethylbenzothiazoline-6sulfonic acid) (ABTS), and DPPH compared to those originated from the Sijunjung and Solok regions [67].

\subsection{Immunomodulatory Properties}

Several studies reported the immunomodulatory properties of LAB in dadih. The salivary secretory immunoglobulin A (sIgA) of underweight Indonesian preschool children was increased significantly $(p<0.05)$ in response to the E. faecium IS-27626 of dadih origin, supplemented at a dose of $2.31 \times 10^{8} \mathrm{cfu} /$ day in $125 \mathrm{~mL}$ of ultra-high temperature (UHT) low-fat milk, after 90 days of supplementation [16]. Besides, weight gain of children with normal body weight was also observed, indicating that E. faecium IS-27626 may help in maintaining the integrity of the intestine, thus facilitating optimum nutrient absorption. The adhesion to and colonization of the mucosal surfaces are possible protective mechanisms against pathogens through competition for binding sites and nutrients or immune modulation [16].

A study reported the effect of L. plantarum IS-10506 of dadih origin $\left(2.3 \times 10^{10} \mathrm{cfu} /\right.$ day $)$ with zinc supplementation ( $20 \mathrm{mg}$ of zinc sulfate/day or $8 \mathrm{mg}$ of zinc elemental/day) on humoral immune response in preschool children after 90 days of supplementation [68]. It was reported that fecal $\operatorname{sigA}$ increased significantly in the probiotic group (30.33 \pm $3.32 \mu \mathrm{g} / \mathrm{g} ; p<0.01)$ and in the combination probiotic and zinc group $(27.55 \pm 2.28 \mu \mathrm{g} / \mathrm{g}$; $p<0.027)$, as compared with the placebo group $(13.58 \pm 2.26 \mu \mathrm{g} / \mathrm{g})$. Furthermore, zinc supplementation can help to improve the zinc status of children [68]. In another study using L. plantarum IS-10506 from dadih as well, it was reported that the increasing production of sIgA in children younger than two years was observed, due to the stimulation of TGF- $\beta 1$ by L. plantarum IS-10506 supplementation. This result was associated with a significant correlation between TGF- $\beta 1 /$ TNF- $\alpha$ and fecal sIgA [69].

The sIgA serves as the first line of defense in protecting the intestinal epithelium from enteric toxins and pathogenic microorganisms. Via the immune exclusion process, sIgA promotes the clearance of antigens and pathogenic microorganisms from the intestinal lumen by blocking their access to epithelial receptors, entrapping them in mucus, and facilitating their removal by peristaltic and mucociliary activities [70]. A study in rats reported that $L$. plantarum Dad-13 contained in the combination with sweet potato fiber may have potency in systemic immune stimulation because of the tendency to increase the level of splenocyte IFN- $\gamma$ in rats infected with S. Typhimurium [17].

\subsection{GABA-Source}

GABA ( $\gamma$-aminobutyric acid) is the major inhibitory neurotransmitter in the mammalian central nervous system [71]. GABA, which effectively acts as a natural relaxant in humans, exists naturally in many kinds of foods at low levels, while higher levels could be found in fermented food products [72]. GABA was also reported to take part in preventing heat-induced stress in broiler chickens [73].

The LAB isolated from indigenous dadih from West Sumatra was reported as a potential producer of GABA, identified as Pediococcus acidilactici [19] and L. plantarum N5 [18]. The optimization of GABA production by P. acidilactici DS15 [74] and L. plantarum [18] were then investigated. The result showed that a higher amount of GABA production was found with the addition of $60 \mathrm{mM}$ glutamate and $100 \%$ whey tofu and $15 \%$ palm sugar were 
the best source of nitrogen and carbon, respectively, for P. acidilactici DS15 [74]. While the highest production of GABA by L. plantarum N5 was observed at pH of 5.5, at a temperature of $36{ }^{\circ} \mathrm{C}$, glutamate concentration of $500 \mathrm{mM}$, and an incubation time of $84 \mathrm{~h}$ [18]. Furthermore, a study characterized the most productive GABA producing LAB, classified as Lactobacillus sp., in various indigenous fermented foods from West Sumatra, such as dadih, ikan budu, asam durian, and tape/tapai, which have anti-stress potential [75]. However, further research is needed to ensure the anti-stress activity of GABA producing LAB is isolated from dadih, especially in humans.

\subsection{Folate-Source}

Dairy products are good sources of folate for humans. Fermented milk products, especially yogurt, can contain a higher amount of folate [76]. In the human diet, folate is involved in many metabolic pathways, mainly in carbon transfer reactions such as purine and pyrimidine biosynthesis and amino acid interconversions [77]. A low intake of folate has been associated with Alzheimer's and coronary heart disease, osteoporosis, increased breast and colorectal cancer, poor cognitive performance, and hearing loss [77]. To date, the isolation and characterization of folate-producing LAB from dadih was reported. A total of 17 isolates from dadih were obtained and based on phenotype and genotype, 16 of them were identified as L. plantarum [20]. The folate production of the 17 selected isolates ranged from 12.43 to $27.84 \mu \mathrm{g} / \mathrm{L}$, and folate production of L. plantarum Dad-13 as the control was $29.27 \mu \mathrm{g} / \mathrm{L}$ [20]. Further research related to the folate-producing ability of LAB from dadih is still needed.

\section{Dadih in the Daily Diet}

Dadih can be consumed directly or can be used in various dishes [22]. In Minangkabau, dadih is usually served during breakfast. Dadih is served with warm rice after adding the condiment, called sambal (ground or sliced shallot and chili) (Figure 3A), or it is added into ampiang (glutinous rice flakes), shaved ice, shredded coconut or coconut milk, and palm sugar syrup as the topping, which is commonly known as "ampiang dadih" [6,31] (Figure 3B). Sometimes, tapioca starch and ginger juice are also added to ampiang dadih [78].

To cook Minang beef curry (Figure 3C), many spices are added, including chili, coriander seeds, cumin, cinnamon, shallot, garlic, ginger, lemongrass, galangal, kaffir lime leaves, cloves, clove leaves, turmeric, and cardamom. Not only the spices, but coconut milk is also one of the main ingredients of beef curry. Dadih can be used as a substitute for coconut milk in beef curry [79].

Besides traditional dishes, dadih is also used in food product development. Some popular food products, such as jelly, beverages, ice cream, sandwiches, and cakes are also developed by using dadih as one of the main components or ingredients [22]. A study reported that ice cream containing dadih decreased the growth of S. typhimurium better than pure ice cream [80].

\section{Challenges and Future Trends of Dadih}

The main problem in dadih production is the decreasing buffalo milk production due to the decreasing buffalo population in West Sumatra [22,35]. Wirawati et al. [35] reported that in 2000, the total population of buffaloes in West Sumatra was 230,818 buffaloes based on Statistics of Sumatera Barat Provinces. In 2015, the population of buffaloes was 121,939 buffaloes [81], and in 2018, the number decreased again to 78,038 buffaloes [82]. The scarcity of buffalo milk may affect the price of buffalo milk and dadih [51]. To support the cultivation of buffalo, as well as the preservation of dadih production in West Sumatra, the West Sumatra Livestock and Animal Health Department initiated and controls a program to provide female buffaloes to local farmers and a buffalo artificial insemination program [83].

Besides the programs from the government, the researchers have studied the alternative ways to solve the limited source of buffalo milk as the main ingredient of dadih, as well as to improve the quality of dadih. The potency of alternative ingredients to alter the 
limited buffalo milk in dadih production was studied, such as cow milk $[35,50,53]$, goat milk $[25,84,85]$, and soy milk $[53,57]$ which are more available than buffalo milk. However, some additional processes, such as evaporation and skim milk addition, are needed to equal the total solid content of buffalo milk to produce dadih with desired properties $[53,84,86]$.

As the sensory properties of dadih may differ due to various LAB used in fermentation and due to spontaneous fermentation in different regions, the protocol of dadih production and microbiota contributed in dadih need to be standardized to make dadih more significant and therefore safer for consumption [6,22]. Besides studying the potency of alternative milk, Taufik [51] reported that pasteurization, controlled fermentation, and changing of dadih containers from bamboo to alternative containers is more sterile and hygienic (e.g., plastic packaging) are also important to make dadih more significant in the food industry. Controlled fermentation of dadih from cow milk using a 3\% starter combination of L. plantarum, L. acidophilus, and Bifidobacterium bifidum was reported [51]. Furthermore, changing packaging material from bamboo tubes to plastic tubes improved the sensory quality and shelf life of dadih made from buffalo milk [87]. However, the development of plastic packaging needs to be investigated, as plastic waste may cause environmental problems. To support the marketing of dadih as a functional food, a study reported on the effective design of dadih packaging, which is obtained based on positive opinion, complete labelling, ergonomics, and large font [88].

To explore the beneficial health properties of dadih, the Dadih Initiative was initiated in Indonesia in 2017 to establish and standardize specifications for production and quality control of dadih, therefore large quantities of dadih production for local people can be achieved [40]. Dadih powder was developed using freezing technology $\left(-20^{\circ} \mathrm{C}, 2\right.$ days), followed by vacuum heating $\left(40-50^{\circ} \mathrm{C}, 5-10 \mathrm{~min}\right)$ for powder stabilization. The nutritional composition of dadih powder was then standardized to be used as a complementary food to prevent children under two years from stunting in West Sumatra, Indonesia [89].

Another development was reported as L. plantarum Dad-13 isolated from dadih was successfully utilized as the starter culture in cheese production. However, it could not be categorized as probiotic cheese due to the low viability of L. plantarum Dad-13 in the resulting cheese [90]. Furthermore, a project developed an incubator for dadih production to accelerate the fermentation time [91]. The incubator was equipped with a digital thermometer to control the temperature during fermentation, and a stopwatch or timer to remind and inform the farmer that the fermentation process is done. By using this incubator at $40{ }^{\circ} \mathrm{C}$, the fermentation time of dadih can be traditionally accelerated from $50 \mathrm{~h}$ to $5 \mathrm{~h}$ [91]. Furthermore, dadih was also involved in improving the nutritional quality (increased fat and protein content) of the cassava waste for animal feed within 10 days of the cassava waste fermentation process [92].

\section{Conclusions}

Buffalo became an important animal for the Minang people for hundreds of years, as every part of the buffalo is very useful to help local people, including as a source of nutrition. Dadih is traditional fermented buffalo milk of the Minangkabau, which is similar to yogurt and Indian dahi. However, they have different production processes, especially the usage of starter culture, heat treatment, production time, and composition of LAB. Dadih has been studied, whether in vitro or in vivo studies, to have potential health benefits. The indigenous LAB found in dadih has antimicrobial, hypocholesterolemic, antimutagenic, antioxidant, and immunomodulatory properties, as well as being a source of GABA (antistress agent) and folate formation. The indigenous microbes, including LAB and yeasts, found in buffalo milk and bamboo tubes also contribute to the formation of flavor and desired texture of dadih. Research is still ongoing to discover the potential health benefits and improve the sensory quality of dadih. However, many challenges were found in dadih production. The decrease in buffalo milk production due to the decreasing population of buffalo in the last two decades was observed. Furthermore, various properties of dadih were observed due to the spontaneous fermentation and the various compositions of microbes 
in buffalo milk and bamboo tubes used in the fermentation. To preserve the production of dadih as the traditional food of the Minangkabau, the local government controls the buffalo cultivation program, while many researchers have studied alternative ways to find alternative milk sources, standardization, and specifications in the dadih fermentation process, and quality control of dadih. With various types of development, dadih will be more significant in the food industry.

Author Contributions: Conceptualization, M.A. and A.G.-M.; methodology, M.A. and Y.V.R.; writingoriginal draft preparation, M.A. and Y.V.R.; writing —-review and editing, M.A. and Y.V.R. and A.G.M.; supervision and funding acquisition, A.G.-M. All authors have read and agreed to the published version of the manuscript.

Funding: This research received no external funding.

Acknowledgments: The authors would like to express sincere gratitude to the European Union and Poznań University of Life Sciences for the "Traditional, Ethnic, and Oriental Food for Human Health" course which provides the platform for the authors to introduce traditional food from Indonesia.

Conflicts of Interest: The authors declare no conflict of interest.

\section{Abbreviations}

ABTS: 2,2'-azino-bis(3-ethylbenzothiazoline-6-sulfonic acid); cfu: colony forming unit; DPPH: 2,2diphenyl-1-picryl-hydrazyl-hydrate; GABA: $\gamma$-aminobutyric acid; LAB: lactic acid bacteria; sIgA: secretory immunoglobulin A; UHT: ultra-high temperature.

\section{References}

1. Statistics Indonesia. Kewarganegaraan, Suku Bangsa, Agama, Dan Bahasa Sehari-Hari Penduduk Indonesia-Hasil Sensus Penduduk 2010; BPS-Statistics Indonesia: Jakarta, Indonesia, 2011.

2. Wahyudi, B.A.; Octavia, F.A.; Hadipraja, M.; Isnaeniah, S.; Viriani, V. Lemang (Rice Bamboo) as a Representative of Typical Malay Food in Indonesia. J. Ethn. Foods 2017, 4, 3-7. [CrossRef]

3. Yovani, T. Lamang Tapai: The Ancient Malay Food in Minangkabau Tradition. J. Ethn. Foods 2019, 6, 22. [CrossRef]

4. Nurmufida, M.; Wangrimen, G.H.; Reinalta, R.; Leonardi, K. Rendang: The Treasure of Minangkabau. J. Ethn. Foods 2017, 4, 232-235. [CrossRef]

5. Rianti, A.; Novenia, A.E.; Christopher, A.; Lestari, D.; Parassih, E.K. Ketupat as Traditional Food of Indonesian Culture. J. Ethn. Foods 2018, 5, 4-9. [CrossRef]

6. Surono, I.S. Indonesian Dadih. In Fermented Milk and Dairy Products; Puniya, A.K., Ed.; CRC Press: Boca Raton, FL, USA, 2015; pp. 377-399.

7. Purwati, E.; Aritonang, S.N.; Melia, S.; Juliyarsi, I.; Purwanto, H. Manfaat Probiotik Bakteri Asam Laktat Dadiah Menunjang Kesehatan Masyarakat; Putra, R.M.S., Ed.; Lembaga Pengembangan Teknologi Informasi dan Komunikasi, Universitas Andalas: Padang, Indonesia, 2016.

8. Akuzawa, R.; Miura, T. Asian Fermented Milks. In Encyclopedia of Dairy Science, 2nd ed.; Fuquay, J.W., Fox, P.F., McSweeney, P.L.H., Eds.; Academic Press: San Diego, CA, USA, 2011; Volume 2, pp. 507-511.

9. Helmizar, H.; Yuswita, E.; Putra, A.E. Analysis of the Nutrients and Microbiological Characteristics of the Indonesian Dadih as a Food Dupplementation. Glob. J. Health Sci. 2019, 11, 155-161. [CrossRef]

10. Harun, H.; Wirasti, Y.; Purwanto, B.; Purwati, E. Characterization of Lactic Acid Bacteria and Determination of Antimicrobial Activity in Dadih from Air Dingin Alahan Panjang District, Solok Regency-West Sumatera. Syst. Rev. Pharm. 2020, 11, 583-586.

11. Pato, U. Potensi Bakteri Asam Laktat Yang Diisolasi Dari Dadih Menurunkan Kolesterol Darah. Agritech 2004, 24, 1-8.

12. Pato, U.; Surono, I.S.; Koesnandar; Hosono, A. Hypocholesterolemic Effect of Indigenous Dadih Lactic Acid Bacteria by Deconjugation of Bile Salts. Asian-Australas. J. Anim. Sci. 2004, 17, 1741-1745. [CrossRef]

13. Surono, I.S. In Vitro Probiotic Properties of Indigenous Dadih Lactic Acid Bacteria. Asian-Australas. J. Anim. Sci. 2003, 16, 726-731. [CrossRef]

14. Surono, I.S.; Pato, U.; Koesnandar; Hosono, A. In Vivo Antimutagenicity of Dadih Probiotic Bacteria towards Trp-P1. AsianAustralas. J. Anim. Sci. 2009, 22, 119-123. [CrossRef]

15. Hapsari, A.; Legowo, A.M.; Pramono, Y.B. Total Lactic Acid Bacteria, PH Values, Soluble Protein and Antioxidant Activity of Dadih Using L. casei and L. plantarum with Different Fermentation Time. J. Appl. Food Technol. 2014, 1, 4-7.

16. Surono, I.S.; Koestomo, F.P.; Novitasari, N.; Zakaria, F.R.; Yulianasari, K. Novel Probiotic Enterococcus Faecium IS-27526 Supplementation Increased Total Salivary SIgA Level and Bodyweight of Pre-School Children: A Pilot Study. Anaerobe 2011, 17, 496-500. [CrossRef] 
17. Nurliyani; Julia, M.; Harmayani, E.; Ikawati, M.; Baliarti, E. Potency of Lactobacillus plantarum Dad-13 and Sweet Potato (Ipomoea batatas) Fiber as Immunomodulator in Rats Infected with Salmonella typhimurium. J. Food Res. 2015, 4, 1. [CrossRef]

18. Harnentis, H.; Nurmiati, N.; Marlida, Y.; Adzitey, F.; Huda, N. $\gamma$-Aminobutyric Acid Production by Selected Lactic Acid Bacteria Isolate of an Indonesian Indigenous Fermented Buffalo Milk (Dadih) Origin. Vet. World 2019, 12, 1352-1357. [CrossRef]

19. Anggraini, L.; Marlida, Y.; Wizna, W.; Jamsari, J.; Mirzah, M.; Adzitey, F.; Huda, N. Molecular Identification and Phylogenetic Analysis of GABA-Producing Lactic Acid Bacteria Isolated from Indigenous Dadih of West Sumatera, Indonesia. F1000Research 2018, 7, 1663. [CrossRef]

20. Purwandhani, S.N.; Utami, T.; Milati, R.; Rahayu, E.S. Isolation, Characterization and Screening of Folate-Producing Bacteria from Traditional Fermented Food (Dadih). Int. Food Res. J. 2018, 25, 566-572.

21. Saifullah; Yulika, F. Perantauan Budaya-Sejarah Minangkabau E Negeri Sembilan; Gunawan, A., Ed.; Institut Seni Indonesia Padangpanjang: Padang Panjang, Indonesia, 2017.

22. Harmayani, E.; Santoso, U.; Gardjito, M. Makanan Tradisional Indonesia Seri 1-Kelompok Makanan Fermentasi Dan Makanan Yang Populer Di Masyarakat; Gadjah Mada University Press: Yogyakarta, Indonesia, 2019.

23. Chandan, R.C.; Shahani, K.M. Yogurt. In Dairy Science and Technology Handbook: Product Manufacturing; Hui, Y.H., Ed.; Wiley-VCH: Euroka, CA, USA, 1993; pp. 1-56.

24. Teuber, M. Fermented Milk Products. In Microbial Safety and Quality of Food; Lund, B.M., Baird-Parker, T.C., Gould, G.W., Eds.; Aspen Publishers: Gaithersburg, MD, USA, 2000; pp. 535-589.

25. Ginting, N. Dadih Bamboo Ampel (Bambusa vulgaris) and Bamboo Gombong (Gigantochloa verticilata) 2 and 3 Days Fermented: Effect on Salad Dressing Hedonic Quality. IOP Conf. Ser. Earth Environ. Sci. 2018, 130, 12029. [CrossRef]

26. Azria, D. Mikrobiologi Dalam Pembuatan Dadih Susu Sapi (Microbiology of Cow Milk Dadih). Bachelor's Thesis, Bogor Agricultural University, Bogor, Indonesia, 1986.

27. Putra, A.A.; Marlida, Y.; Khasrad, K.; Azhike, S.Y.D.; Wulandari, R. Perkembangan Dan Usaha Pengembangan Dadih: Sebuah Revieiw Tentang Susu Fermentasi Tradisional Minangkabau (Recent Situation and Development Efforts of Dadih: A Review of Minangkabau Traditional Fermentation Milk). J. Peternak. Indones. 2011, 13, 159-170.

28. Maslami, V.; Marlida, Y.; Mirnawati, J.; Nur, Y.S.; Adzitey, F.; Huda, N. A Review on Potential of Glutamate Producing Lactic Acid Bacteria of West Sumatera's Fermented Food Origin, as Feed Additive for Broiler Chicken. J. World's Poult. Res. 2018, 8, 120-126.

29. Surono, I.S. Ethnic Fermented Foods and Beverages of Indonesia. In Ethnic Fermented Foods and Alcoholic Beverages of Asia; Tamang, J.P., Ed.; Springer: New Delhi, India, 2016; pp. 341-382.

30. Khedkar, C.D.; Kalyankar, S.D.; Deosarkar, S.S.; Patil, A.M. Dahi. In Encyclopedia of Food and Health; Caballero, B., Finglas, P.M., Toldrà, F., Eds.; Academic Press: Cambridge, MA, USA, 2016; pp. 345-351.

31. Surono, I.S.; Hosono, A. Indigenous Fermented Foods in Indonesia. Jpn. J. Dairy Food Sci. 1995, 44, 91-98.

32. Jatmiko, Y.D.; Howarth, G.S.; Barton, M.D. Evaluation of Yeast Diversity in Dadih and Dangke Using PCR-RFLP of Internal Transcribed Spacer Region. IOP Conf. Ser. Earth Environ. Sci. 2019, 391, 12025. [CrossRef]

33. Sunarlim, R. Potensi Lactobacillus sp. Asal Dari Dadih Sebagai Starter Pada Pembuatan Susu Fermentasi Khas Indonesia. Bul. Teknol. Pascapanen Pertan. 2009, 5, 69-76.

34. Surono, I.S.; Nurani, D. Exploration of Indigenous Lactic Acid Bacteria from Dadih of West Sumatra for Good Starter Cultures and Probiotic Bacteria; Domestic Collaborative Research Grant Program(DCRG), URGE Project, 2000-2001; Research Report; Directorate General of Higher Education, Ministry of Education and Culture: Indonesia, 2001.

35. Wirawati, C.U.; Sudarwanto, M.B.; Lukman, D.W.; Wientarsih, I. Karakteristik Dan Pengembangan Dadih Dari Susu Sapi Sebagai Alternatif Dadih Susu Kerbau (Characteristic and Development of Cow's Milk Dadih as an Alternate of Buffalo's Milk Dadih). WARTAZOA 2017, 27, 95-103. [CrossRef]

36. Hosono, A.; Wardoyo, R.; Otani, H. Microbial Flora in Dadih, a Traditional Fermented Milk in Indonesia. Leb. Technol. 1989, 22, 20-24.

37. Nuraida, L. A Review: Health Promoting Lactic Acid Bacteria in Traditional Indonesian Fermented Foods. Food Sci. Hum. Wellness 2015, 4, 47-55. [CrossRef]

38. Hosono, A.; Wardoyo, R.; Otani, H. Binding of Amino Acid Pyrolyzates by Lactic Acid Bacteria Isolated from Dadih. Leb. Technol. 1990, 23, 149-153.

39. Wirawati, C.U.; Sudarwanto, M.B.; Lukman, D.W.; Wientarsih, I.; Srihanto, E.A. Diversity of Lactic Acid Bacteria in Dadih Produced by Either Back-Slopping or Spontaneous Fermentation from Two Different Regions of West Sumatra, Indonesia. Vet. World 2019, 12, 823-829. [CrossRef]

40. Venema, K.; Surono, I.S. Microbiota Composition of Dadih-A Traditional Fermented Buffalo Milk of West Sumatra. Lett. Appl. Microbiol. 2019, 68, 234-240. [CrossRef]

41. Jatmiko, Y.D.; Lopes, M.D.B.; Barton, M.D. Molecular Identification of Yeasts Isolated from Dadih by RFLP-PCR and Assessment on Their Ability in Utilizing Lactate. Microbiol. Indones. 2012, 6, 30-34. [CrossRef]

42. De Hernández-Cánovas, J.D.; Guillén-López, I.; Vizcaíno-Milla, P.; Andreo-López, M.I.; Sánchez-Rubio, M.; Taboada-Rodríguez, A.; Marín-Iniesta, F. Antimicrobial Activity of Citrus spp. and Anethum graveolens Components against Candida Metapsilosis in Ranch Sauce. J. Food Sci. Technol. 2020, 57, 2713-2721. [CrossRef] 
43. Resende, L.V.; Pinheiro, L.K.; Miguel, M.G.C.P.; Ramos, C.L.; Vilela, D.M.; Schwan, R.F. Microbial Community and Physicochemical Dynamics during the Production of 'Chicha', a Traditional Beverage of Indigenous People of Brazil. World J. Microbiol. Biotechnol. 2018, 34, 46. [CrossRef]

44. Elida, M. Profil Bakteri Asam Laktat Dari Dadih Yang Difermentasi Dalam Berbagai Jenis Bambu Dan Potensinya Sebagai Probiotik. Master's Thesis, Bogor Agricultural University, Bogor, Indonesia, 2002.

45. Sunaryanto, R.; Marwoto, B. Isolasi, Identifikasi, Dan Karakterisasi Bakteri Asam Laktat Dari Dadih Susu Kerbau. J. Sains dan Teknol. Indones. 2012, 14, 228-233. [CrossRef]

46. Syukur, S.; Rijal, F.; Jamsari; Purwati, E. Isolation and Molecular Characterization of Lactic Acid Bacteria by Using 16s RRNA from Fermented Buffalo Milk (Dadih) in Sijunjung, West Sumatera. Res. J. Pharm. Biol. Chem. Sci. 2014, 5, 871-876.

47. Purwati, E.; Syukur, S.; Husmaini; Purwanto, H.; Pasaribu, R.P. Molekuler Karakterisasi Bakteri Asam Laktat Isolate Dadih Air Dingin Kabupaten Solok Sumatera Barat. J. Penelit. Inov. 2014, 40, 134-146.

48. Harlina, D. Isolasi Dan Seleksi Bakteri Asam Laktat Dari Dadih Dalam Menghasilkan Asam Glutamat. Bachelor's Thesis, Andalas University, Padang, West Sumatra, Indonesia, 2016.

49. Usmiati, S.; Risfaheri. Improvement of Dadih as an Indigenous Probiotic Functional Food of West Sumatra. J. Litbang Pertan. 2013, 32, 20-29.

50. Usmiati, S.; Broto, W.; Setiyanto, H. Karakteristik Dadih Susu Sapi Yang Menggunakan Starter Bakteri Probiotik. JITV 2011, 16, 140-152.

51. Taufik, E. Dadih Susu Sapi Hasil Fermentasi Berbagai Starter Bakteri Probiotik Yang Disimpan Pada Suhu Rendah: Karakteristik Kimiawi. Media Peternak. 2004, 27, 88-100.

52. Afriani, A. Kualitas Dan Aktivitas Antimikroba Produk Dadih Susu Sapi Pada Penyimpanan Suhu Rendah. Agrinak 2012, 2, 11-16.

53. Dasril, O.; Putri, G.E.; Amar, S. Comparison of Nutritional Quality and Organoleptic of Dadih(Minangkabau Traditional Yogurt) of Cow Milk and Soy Milk as Functional Food Probiotics. Glob. J. Med. Res. 2019, 19, 21-24.

54. Wijayanti, M.; Thohari, I.; Purwadi, P. Manufacture of Goat Milk Dadih Incubated Using Variety of Bambooes. J. Ilmu dan Teknol. Has. Ternak 2016, 11, 22-37. [CrossRef]

55. Harnentis, H.; Marlida, Y.; Nur, Y.S.; Wizna, W.; Santi, M.A.; Septiani, N.; Adzitey, F.; Huda, N. Novel Probiotic Lactic Acid Bacteria Isolated from Indigenous Fermented Foods from West Sumatera, Indonesia. Vet. World 2020, 13, 1922-1927. [CrossRef]

56. Syukur, S.; Hermansyah, A.; Fachrial, E. Probiotics and Strong Antimicrobial of Buffalo Milk Fermentation (Dadih) from Different Places in West Sumatera Indonesia. Res. J. Pharm. Biol. Chem. Sci. 2016, 7, 386-392.

57. Retnaningrum, E.; Yossi, T.; Nur'azizah, R.; Sapalina, F.; Kulla, P.D.K. Characterization of a Bacteriocin as Biopreservative Synthesized by Indigenous Lactic Acid Bacteria from Dadih Soya Traditional Product Used in West Sumatra, Indonesia. Biodiversitas 2020, 21, 4192-4198. [CrossRef]

58. Alakomi, H.L.; Skyttä, E.; Saarela, M.; Mattila-Sandholm, T.; Latva-Kala, K.; Helander, I.M. Lactic Acid Permeabilizes GramNegative Bacteria by Disrupting the Outer Membrane. Appl. Environ. Microbiol. 2000, 66, 2001-2005. [CrossRef] [PubMed]

59. El-Shouny, W.; Abo-Kamar, A.; El-Shanshoury, A.E.-R.; Ragy, S. Production of Plantarcin by Lactobacillus plantarum SR18. J. Microbiol. Biotechnol. Food Sci. 2012, 1, 1488-1504.

60. Bengtsson, T.; Selegård, R.; Musa, A.; Hultenby, K.; Utterström, J.; Sivlér, P.; Skog, M.; Nayeri, F.; Hellmark, B.; Söderquist, B.; et al. Plantaricin NC8 A $\beta$ Exerts Potent Antimicrobial Activity against Staphylococcus spp. and Enhances the Effects of Antibiotics. Sci. Rep. 2020, 10, 3580 .

61. Pato, U.; Yusuf, Y.; Fitriani, S.; Jonnadi, N.N.; Sri Wahyuni, M.; Feruni, J.A.; Jaswir, I. Inhibitory Activity of Crude Bacteriocin Produced by Lactic Acid Bacteria Isolated from Dadih against Listeria monocytogenes. Biodiversitas 2020, 21, 1295-1302. [CrossRef]

62. Yuliana, T.; Hayati, F.; Cahyana, Y.; Rialita, T.; Mardawati, E.; Harahap, B.M.; Safitri, R. Indigenous Bacteriocin of Lactic Acid Bacteria from "Dadih" a Fermented Buffalo Milk from West Sumatra, Indonesia as Chicken Meat Preservative. Pak. J. Biol. Sci. 2020, 23, 1572-1580. [CrossRef] [PubMed]

63. Pato, U.; Ali, M.; Parlindungan, A.K. Taurocholate Deconjugation and Cholesterol Binding by Indigenous Dadih Lactic Acid Bacteria. HAYATI J. Biosci. 2005, 12, 103-107. [CrossRef]

64. Surono, I.S.; Hosono, A. Antimutagenicity of Milk Cultured with Lactic Acid Bacteria from Dadih against Mutagenic Terasi. Milchwissenschaft 1996, 51, 347-363.

65. Pato, U. Bile and Acid Tolerance of Lactic Acid Bacteria Isolated from Dadih and Their Antimutagenicity against Mutagenic Heated Tauco. Asian-Australas. J. Anim. Sci. 2003, 16, 1680-1685. [CrossRef]

66. Akuzawa, R.; Miura, T.; Kawakami, H. Bioactive Components in Caseins, Caseinates, and Cheeses. In Bioactive Components in Milk and Dairy Products; Park, Y.W., Ed.; Wiley-Blackwell: Ames, Iowa, 2009; pp. 217-233.

67. Kusumaningtyas, E.; Utami, A. Antioxidant Activity of Soluble Protein from Natural Fermented Buffalo Milk. IOP Conf. Ser. Earth Environ. Sci. 2020, 457, 12037. [CrossRef]

68. Surono, I.S.; Martono, P.D.; Kameo, S.; Suradji, E.W.; Koyama, H. Effect of Probiotic L. plantarum IS-10506 and Zinc Supplementation on Humoral Immune Response and Zinc Status of Indonesian Pre-School Children. J. Trace Elem. Med. Biol. 2014, 28, 465-469. [CrossRef]

69. Kusumo, P.D.; Bela, B.; Wibowo, H.; Munasir, Z.; Surono, I.S. Lactobacillus plantarum IS-10506 Supplementation Increases Faecal SIgA and Immune Response in Children Younger than Two Years. Benef. Microbes 2019, 10, 245-252. [CrossRef] 
70. Mantis, N.J.; Rol, N.; Corthésy, B. Secretory IgA's Complex Roles in Immunity and Mucosal Homeostasis in the Gut. Mucosal Immunol. 2011, 4, 603-611. [CrossRef]

71. Olsen, R.W.; Li, G.D. GABA. In Basic Neurochemistry; Brady, S.T., Siegel, G.J., Albers, R.W., Price, D.L., Eds.; Academic Press: Cambridge, MA, USA, 2012; pp. 367-376.

72. Abdou, A.M.; Higashiguchi, S.; Horie, K.; Kim, M.; Hatta, H.; Yokogoshi, H. Relaxation and Immunity Enhancement Effects of $\gamma$-Aminobutyric Acid (GABA) Administration in Humans. BioFactors 2006, 26, 201-208. [CrossRef]

73. Dai, S.F.; Gao, F.; Xu, X.L.; Zhang, W.H.; Song, S.X.; Zhou, G.H. Effects of Dietary Glutamine and Gamma-Aminobutyric Acid on Meat Colour, PH, Composition, and Water-Holding Characteristic in Broilers under Cyclic Heat Stress. Br. Poult. Sci. 2012, 53, 471-481. [CrossRef]

74. Anggraini, L.; Marlida, Y.; Wizna, W.; Jamsari, J.; Mirzah, M. Optimization of Nutrient Medium for Pediococcus acidilactici DS15 to Produce GABA. J. World's Poult. Res. 2019, 9, 139-146. [CrossRef]

75. Anggraini, L.; Marlida, Y.; Mirzah, M.; Wizna, J.; Huda, N. Isolation and Characterization of Lactic Acid Bacteria Producing GABA from Indigenous West Sumatera Fermented Food. Int. J. Adv. Sci. Eng. Inf. Technol. 2019, 9, 855-860. [CrossRef]

76. Crittenden, R.G.; Martinez, N.R.; Playne, M.J. Synthesis and Utilisation of Folate by Yoghurt Starter Cultures and Probiotic Bacteria. Int. J. Food Microbiol. 2003, 80, 217-222. [CrossRef]

77. Iyer, R.; Tomar, S.K. Folate: A Functional Food Constituent. J. Food Sci. 2009, 74, R114-R122. [CrossRef]

78. Gardjito, M.; Muliani, L.; Chayatinufus, C. Pusaka Nenek Moyang, Yang Pantas Disayang—Kuliner Minangkabau; Hardiman, I., Ed.; PT Gramedia Pustaka Utama: Jakarta, Indonesia, 2019.

79. Wongso, W.W. Ceritarasa William Wongso_-Kumpulan Resep Alternatif; PT Gramedia Pustaka Utama: Jakarta, Indonesia, 2009.

80. Rezvi, S.; Putra, A.E.; Faadhila, T. In Vivo Antibacterial Activity of Dadih and Dadih Ice Cream toward Salmonella typhimurium Development. Ann. Glob. Health 2017, 83, 156-169. [CrossRef]

81. Statistics of Sumatera Barat Provinces. Provinsi Sumatera Barat Dalam Angka (Sumatera Barat Provinces in Figures) 2016; BPS-Statistics of Sumatera Barat Provinces: Padang, Indonesia, 2016.

82. Statistics of Sumatera Barat Provinces. Provinsi Sumatera Barat Dalam Angka (Sumatera Barat Provinces in Figures) 2019; BPS-Statistics of Sumatera Barat Provinces: Padang, Indonesia, 2019.

83. West Sumatra Livestock and Animal Health Department. Inseminasi Buatan, Meningkatkan Populasi Sapi. Available online: https:// sumbarprov.go.id/home/news/2014-inseminasi-buatan-meningkatkan-populasi-sapi.html (accessed on 20 November 2020).

84. Afrizal, A. Pengaruh Pemberian Susu Bubuk Skim Terhadap Kualitas Dadih Susu Kambing (The Influence of Skim Milk Powder to the Goat Milk's Curd Quality). J. Ilm. Fill. Cendekia 2019, 4, 88-94.

85. Febrina, N.N.T.; Bahri, S.; Rasmi, D.A.C. Susu Segar Kambing Etawa Yang Difermentasi Dalam Bambu Betung (Dendrocalamus asper) Dan Bambu Tali (Gigantochloa apus) Sebagai Probiotik Bakteri Asam Laktat. J. Pijar MIPA 2019, 14, 89-94. [CrossRef]

86. Ulfa, M.; Sugitha, I.M.; Trisna Darmayanti, L.P. Pengaruh Penambahan Skim Terhadap Karakteristik Dadih Susu Sapi Yang Dibuat Dalam Ruas Bambu Wuluh (Schizostachyum silicatum) Di Bali. J. Ilmu Dan Teknol. Pangan 2020, 9, 211. [CrossRef]

87. Sisriyenni, D.; Zurriyati, Y. Kajian Kualitas Dadih Susu Kerbau Di Dalam Tabung Bambu Dan Tabung Plastik. J. Pengkaj. Dan Pengemb. Teknol. Pertan. 2004, 7, 171-179.

88. Delfitriani; Djatna, T. Construction of Business Intelligence in Dadih Product Affective Design. IOP Conf. Ser. Earth Environ. Sci. 2019, $230,12053$.

89. Helmizar, H.; Surono, I.S.; Saufani, I.A. Development of Dadih Powder as a Complementary Food to Prevent Children from Stunting in West Sumatra, Indonesia. IOP Conf. Ser. Earth Environ. Sci. 2020, 583, 12027. [CrossRef]

90. Meidistria, T.R.; Sembiring, L.; Rahayu, E.S.; Haedar, N.; Dwyana, Z. Survival of Lactobacillus plantarum Dad 13 in Probiotic Cheese Making. IOP Conf. Ser. Earth Environ. Sci. 2020, 575, 12020.

91. Amri, K.; Putra, A.A. Introduksi Incubator Buatan Untuk Mempersingkat Waktu Pembuatan Dadih. J. Tek. Mesin 2012, 9, 46-52. [CrossRef]

92. Ginting, N. Comparison of Isolate Dadih with Yeast Dadih in Improving Nutrition Quality of Cassava Waste (CW). IOP Conf. Ser. Earth Environ. Sci. 2018, 141, 12008. [CrossRef] 